\title{
Making Implementation Deed Electronically Based on Law of Notary
}

\author{
Yudha Prio Kuspratomo1, Lailatul Nur Hasanah ${ }^{2}$ and Sri Endah \\ Wahyuningsih $^{3}$
}

Abstract. The purpose of this study was to: 1) To know and analyze the mechanisms of electronic deed made by the notary. 2) To analyze the obstacles faced by the notary in the manufacture of electronic certificates. The method used in this empirically is sociological juridical data used in this study are primary data and secondary data, primary data obtained by conducting interviews with Indonesian Notary Association, and secondary data obtained by reviewing book. Found of data analysis concluded that: 1) the Indonesian Notary Association until now was not serious to realize implementation electronically authentic deed. With electronic media, notaries become more efficient administration. 2) Barriers cyber Notary the notary system management. Managed the Ministry of Justice and Human Rights of the Republic of Indonesia or the Indonesian Notaries Association organization. Because the office of notary is an independent, preferably Indonesian Notary Association has its own system that will manage the cyber Notary and can be used by all notaries Indonesia. Harmonization Act as a way out for the development of cyber Notary in Indonesia.

Keywords: Deed Electronics; Cyber Notary; UUJN.

\section{Introduction}

More simplify operations and business activities in Indonesia, the government issued a package of economic policy today wants to increase business by cutting bureaucracy considered licensing and investment slows. It impacted by the acceleration of system services and construction sectors.

Indisputable fact is in line with the economic growth in the mushrooming growth of banking to remote areas. It requires a notary as an authentic deed officials cannot be ignored. That is the role of the notary for the state, its existence is a requirement that every minute and even seconds are needed to assist countries in the field of private law would also state administration. ${ }^{4}$

According Widhi Handoko, the law should be adjusted to the growth and dynamics of life. Not only serves realize the security and public order. Furthermore, it should create greater prosperity for the people. ${ }^{5}$

Because of the progressive element, the law becomes a dynamic, evolving following the situation and conditions of the community. Laws like this brings breakthroughs and updates required by the community. Community development is a natural, legal

\footnotetext{
${ }^{1}$ Student Master of Notary Program, Faculty of Law, Sultan Agung Islamic University Semarang, Email: yupikuyupiku@gmail.com

${ }^{2}$ Student of Master of Law, Faculty of Law, Sultan Agung Islamic University Semarang, email lailanurhasna@gmail.com

${ }_{3}^{3}$ Lecturer, Faculty of Law, Sultan Agung Islamic University Semarang

${ }^{4}$ Widhi Handoko, 2019, Dominasi Negara Terhadap Notaris Antara Ide dan Realita, Publika Kreasi, Bogor, p. 42.

5 ibid, p. 42
} 
Mandatory follow these developments, so as to facilitate them to achieve the ideals of life. $^{6}$

The development of information technology so rapidly these days have brought various significant impact in the life of mankind. Various facilities offered by the telecommunications development has allowed the relationship between human beings can be done quickly and easily without taking into account aspects of space and time. That information technology is the basis of all aspects of life, ranging from economic, social, cultural, educational, to the law. Since the issuance of Law No. 19 of 2016 as an amendment of Law No. 11 of 2008 on Information and Electronic Transactions (ITE), slowly but surely buying and selling shifted from conventional to electronic-based, then recommend e-Commerce.

Certification transactions using cyber Notary is an explanation of Article 15 (3) of the Constitution - Law No. 2 of 2014 is less well understood, even if it is interpreted as an endorsement of a transaction made in cyber Notary resulting transaction is considered a notarial deed then it clearly has been contrary to Article 16 paragraph (1) letter $\mathrm{m}$ Law No. 2 of 2014 concerning Notary. Where it does not agree with the way the notary deed as authentic deeds that have been regulated in Article 16 paragraph (1) letter $\mathrm{m}$ Law No. 2 of 2014 explains that the notary shall read out the deed before attendant, attended by two (2) witnesses, While cyber Notary here attendant indirect position before a notary public, but through an electronic device such as a teleconference or Video Call. To realize the happiness of individuals and society the law must reach the goal to provide subsistence (to provide for life), to Provide abundance (to provide a living food is plentiful), to provide security (for protection), and to ATTAIN equity (to achieve equation). ${ }^{7}$

Law No. 2 of 2014 gave way to a notary to carry out its duties through the electronic system, which is mentioned in Article 15 paragraph (3) of the Constitution - Law No. 2 of 2014 which reads "What is meant by" other powers stipulated in legislation ", among other things, the authority to certify transactions carried out electronically (cyber notary), a deed, pledge endowments, and mortgage aircraft." Article 15 (3) of the Constitution - Law No. 2 of 2014 states that a notary can legally perform their duties electronically. The contents of Article 15 paragraph (3) of the Constitution - Law No. 2 of 2014 indirectly also stated that the notary is part of the organizers of the electronic transaction deed transactions electronically. In general, said that the electronic information and / or electronic documents and / or prints with a valid legal evidence, which is an extension of the valid evidence in accordance with the Law of Procedure applicable in Indonesia. Likewise with electronic signatures, has no legal force and effect of law is legitimate. However, the manufacture of electronic signatures must meet specified requirements. ${ }^{8}$

Furthermore, for legal certainty and legal benefit for the community, the need for harmonization of the Act relating to the authority of the notary in the manufacture of electronic certificates. So that the notary no longer experience problems concerning juridical authority in a deed electronically.

\footnotetext{
6 ibid p. 44

7 Jeremy Bentham, 2016, Teori Perundang Undangan, Prinsip-Prinsip Legalisasi, dan Hukum Perdata, Nuansa Cendikia, Jakarta, p. 18.

8 Kemenkumham, Ditjen Peraturan Perundang-undangan, Hukum Teknologi Informasi (Telematika), http://ditjenpp.kemenkumham.go.id/hukum teknologi/661-keabsahan-alat-buktielektronik-dlm-suatu-perjanjian-dlm-penyelesaian-sengketa-melalui-arbitrase-onl.html, accessed on 24 September 2019 at 08.00.
} 
Volume 6 Issue 4, December 2019

Nationally Accredited Journal,

Decree No. B/4130/E5/E5.2.1/2019

\section{Research methods}

This study uses a method socio-juridical. Judicial approach in this study is the consideration or the reasons which illustrate that the rules established to deal with legal issues or fill a legal vacuum by considering the existing rule, which will be changed, or that will be revoked to ensure legal certainty and a sense of justice. Juridical basis concerning legal issues relating to the substance or material that is arranged so need to be established Regulation Legislation new.

\section{Results and Discussion}

\subsection{Making Mechanism Electronic By Notarial Deed}

Law No. 30 of 2004 concerning Notary formed, because the rules relic of colonial Dutch East Indies was considered no longer relevant to the development and needs of the people of Indonesia law. With the aim of unification of the creation of the law applicable to the public, as renewal and rearrangement overall, the Act No. 2 of 2014 concerning amendments to the Law No. 30 of 2004 concerning Notary. ${ }^{9}$

Notary is a public official authorized to make an authentic deed and have more authority as referred to in Law No. 2 of 2014 or the other Act. ${ }^{10}$ Therefore, in order to achieve certainty and legal protection, the application of the precautionary principle should be run in accordance with the precautionary principle Notary, if established a good relationship, mutual understanding between the Notary and the parties, violations of the law can be avoided. ${ }^{11}$

Law is one of the means needed by everyone in his life to fill, especially in the economic system that entered the era of globalization. The need is manifested in the form of a clear legal product and have legal certainty as well as law-enforcement actions of law enforcement officers. ${ }^{12}$ To ensure certainty, order and legal protection required written evidence that is authentic about the circumstances, events or legal actions made before certain officials. Notaries are certain positions that practicing a profession in legal services to people who need protection and guarantees in order to achieve legal certainty. Notary as a public official (openbaar ambtenaar) in carrying out their profession must be professional because the notary represents the state in performing its duties and its social function in deed as evidence in the form of an authentic deed. The presence of notary agencies due to increasing needs of the community both in ancient times and today. The state also regulates the interests of citizens and maintaining stability and law and order, which in turn is to create directionally varying conditions desired social welfare society. ${ }^{13}$

Revised Law Notary cannot be delayed any longer. The living conditions of the people

\footnotetext{
${ }^{9}$ GHS Lumban Tobing, 1983, Peraturan Jabatan Notaris, Erlangga, Jakarta, p. 20

10 Ngadino, 2018, Tugas Dan Tanggug Jawab Notaris di Indonesia, PGRI Semarang Press, Semarang, p. 3.

${ }^{11}$ Sri Endah Wahyuningsih, 2017, "Prinsip Kehati-Hatian Bagi Notaris/PPAT Dalam Upaya

Pencegahan Kriminalisasi Berdasarkan Kode Etik", Jurnal Akta: Vol. 4 No. 3 September 2017 Url: unissula.com/jurnal.unissula.ac.id/index.php/akta/article/viewFile/1807/1356

12 Andi Prajitno 2010, Pengetahuan Praktis Tentang Apa dan Siapa Notaris di Indonesia, CV. Son Media Nusantara in Surabaya, p. 11.

${ }^{13}$ Great, 2015, Utilitarianisme Dan Tujuan Perkembangan Hukum Multimedia Di Indonesia,
} Gramedia, Jakarta, p. 62 
of Indonesia have proven that the absence of legislation will result in the emergence of various forms of anxiety in running a virtual activity, especially in the system of electronic services carried out by a notary. ${ }^{14}$

Service by using technology-based system that will systematically processed to produce technology that is timely, efficient, and reliable. Notary world is a mix between theory and practice in an ideal level between theory and practice in line or sometimes not mutually incompatible. That is not always the theory support the practice, so that the world notary must be built not just taken and developed by the theories of jurisprudence that has been there, but the notary must also develop their own theories to support the execution of duties of office notary and experiences during the run job notary office. Cyber Notary can be used as a concept that uses electronic media and to contribute in the form of field notary services in Indonesia.

\subsection{Barriers Notary Deed In the Create Electronic}

Constraints on managing cyber Notary system. Managed the Ministry of Justice and Human Rights of the Republic of Indonesia or the Indonesian Notaries Association organization. Because the office of notary is an independent, preferably Indonesian Notary Association has its own system that will manage the cyber Notary and can be used by all notaries Indonesia.

In the development of electronic services and transaction security is guaranteed. To facilitate the modernization of public services especially in the manufacture of authentic deed or task and authority as stipulated in Article 15 UUJN so far not realized by the Indonesian Notaries Association organization.

E-notarial or electronic notary create, organize and store electronic documents. All using notary deed made without paper. Its realization depends on state policy. Most of them use the symbol notary stamp to mark the document and also legalize the certificate for authentication. E-notary does not mean that a notary can carry out their duties only with a web camera. Still the attendant to be face to face, so the notary can immediately see with own eyes that attendant sign and affix their fingerprints to the deed. ${ }^{15}$

Indonesian Notary Association can begin to develop an electronic certificate technology systems to ensure the industry 4.0 is reached. Not issued regulations that could potentially create notaries exercise its authority.

Utilization of information technology in the manufacture of electronic notarial deed is certainly not only benefits, but also poses some problems. The advantage of the electronic notary deed, between time and cost efficiency. However, it also raised several issues related to the law. Development of society so quickly inversely proportional to the development of law in Indonesia always miss.

Arised in deed authentic electronically is linked to the obligations which must be done by a notary of the deed he made, as provided for in Article 16 (1) UUJN, particularly Article 16 paragraph (1) UUJN c and m, which reads: 1. Reattaching letters and documents and fingerprints attendant on Minuta Deed; 2. Reading Deed before attendant in the presence of at least two (2) witnesses, or four (4) witnesses to a deed

14 Emma Nurita 2012, Cyber Notary Pemahaman Awal dalam Konsep Pemikiran, Refika Aditama, Bandung, p. 25.

15 Widhi Handoko, 2019, Dominasi Negara Terhadap Notaris Antara Ide dan Realita, Roda Republika Kreasi, Bogor, p. 119. 
Volume 6 Issue 4, December 2019

Nationally Accredited Journal,

Decree No. B/4130/E5/E5.2.1/2019

will specifically under the hand, and signed on the spot by attendant, witnesses and a notary.

Based on the two forms of the type made by notary deed, to today's highly not possible to apply information technology in the manufacture of electronic notarial deed. Especially in deed relaas. Here, the presence of a notary public in the presence of the parties is a necessity so that it can be made the official report which contains a description of the notary had seen and witnessed by a notary public at the request of the parties themselves.

Furthermore, when referring to the provisions of Article 5, paragraph (4) letter a and b UU ITE, it is known that the documents created in the form of a deed notary is not included in the electronic information and / or electronic documents. So the notary deed made electronically no legal power as valid evidence under the terms of the ITE Law. With restrictions significance of electronic information / electronic documents set out in Article 5 (4) a and b, then the authentic deed that is created electronically by $a$ notary public can not be considered valid evidence. Thus, the authenticity of the deed made by the notary in this case are not met. ${ }^{16}$

\section{Closing}

\subsection{Conclusion}

Based on the research results can be concluded as follows:

- The role of the notary in line with government law politics in the deed relating to the establishment of the company, in order to meet regulatory ease of doing business in Indonesia. Free gaining recognition as a legal entity and registration at the relevant agencies conducted through electronic relationship with the Department of Justice through Legal Entity Administration System (SABH). With the involvement of a notary and their OSS and SABH has looked at the progress in the ease to start a business so as to encourage investment both at home and from abroad.

- Indonesian Notary Association until now was not serious to realize implementation electronically authentic deed. Amid the development of digital technology and the need for efficiency of service also ease of doing business in Indonesia Ease of Doing Business (EODB), where the role, function, and the presence of the actual notary.

\subsection{Suggestion}

- Indonesian Notary Association to support state programs for the advancement of social justice and inequality. Notary participate actively assisting progress in the field of information and communication technologies that have a positive impact on the state and society.

- Legal certainty and legal benefit for the community, the need for harmonization of the Act relating to the authority of the notary in the manufacture of electronic certificates.

16 Rini Irianti Sundary, April 20, 2018, "Legal Issues Creation Deed In Electronic"https://www.unisba.ac.id/en/masalah-hukum-pembuatan-akta-notaris-secaraelectronic/ , Accessed on December 11, 2019 


\section{References}

[1] Andi Prajitno, 2010, Pengetahuan Praktis Tentang Apa dan Siapa Notaris di Indonesia, CV. Putra Media Nusantara, Surabaya.

[2] Besar, 2015, Utilitarianisme Dan Tujuan Perkembangan Hukum Multimedia Di Indonesia, Gramedia, Jakarta.

[3] Emma Nurita, 2012, Cyber Notary Pemahaman Awal Dalam Konsep Pemikiran, Refika Aditama, Bandung.

[4] G.H.S Lumban Tobing, 1983, Peraturan Jabatan Notaris, Erlangga, Jakarta.

[5] Jeremy Bentham, 2016, Terori Perundang Undangan, Prinsip-Prinsip Legalisasi, dan Hukum Perdata, Nuansa Cendikia, Jakarta.

[6] Ngadino, 2018, Tugas Dan Tanggung Jawab Notaris di Indonesia, Univ. PGRI Semarang.

[7] Widhi Handoko, 2019, Dominance Against Notary Between Idea and Widhi Handoko, 2019, Dominasi Terhadap Notaris Antara Ide dan Realita, Roda Publika Kreasi, Bogor.

[8] Journal: Sri Endah Wahyuningsih, 2017, Jurnal: Sri Endah Wahyuningsih, 2017, "Prinsip Kehati-Hatian Bagi Notaris/PPAT Dalam Upaya Pencegahan Kriminalisasi Berdasarkan Kode Etik", Journal of Deeds: Vol. 4 No. 3 September 2017 Url: unissula.com/jurnal.unissula.ac.id/index.php/akta/article/viewFile/1807/1356

[9] Journal: Daulat P. Silitonga, 2019, "Derupsi Digital Bukan Hanya Tantangan, Tapi Juga Peluang", in Notary Magazine, url: https://notarymagazine.com/disrupsidigital-bukan-saja-tantangan-tapi-juga-peluang/

[10] Web: Rini Iritanti Sundary, April 20, 2019, the Legal Issues of Electronic Creation Deed, accessed on December 11, 2019.

[11] Web: Kemenkumham Ditjen Peraturan Perundang-undangan, Hukum Teknologi Informasi (Telematika), http://ditjenpp.kemenkumham.go.id/hukum teknologi/661-keabsahan-alat-bukti-elektronik-dlm-suatu-perjanjian-dlmpenyelesaian-sengketa-melalui-arbitrase-onl.html, accessed on 24 September 2019 at 08.00.

[12] Legislation: The Book of the Law of Civil Law.

[13] Legislation: Law No. 2 of 2014 On Notary.

[14] Legislation: Law No. 19 of 2016 on Information and Electronic Transactions.

[15] Government Regulation No. 82 of 2012Tentang Operation System and Electronic Transactions. 